\title{
EFFECT OF THE NEONATAL ADMINISTRATION OF A SINGLE DOSE OF CHLORPROMAZINE ON THE SUBSEQUENT SEXUAL DEVELOPMENT OF MALE MICE
}

\author{
P. J. HOGARTH AND P. GHALMERS \\ Biology Department University of York, Heslington, York YO1 5DD
}

(Received 9th February 1973)

\begin{abstract}
Summary. A single injection of $20 \mu \mathrm{g}$ chlorpromazine/g body weight given on Days $4,6,7,8,9$ and 10 resulted in greater testis and seminal vesicle weight, and a general increase in spermatogenesis assessed at 30 days of age. A considerably greater effect was obtained when the injection was given on Day 7 compared with injection on any other day.
\end{abstract}

The critical significance of the early postnatal period in mice and rats to subsequent sexual development is well established (Harris, 1964; Barraclough, 1966, 1968). Injection of female neonates with androgens results in suppression of the phasic hypothalamic control of gonadotrophin secretion which is typical of the female and allows only the expression of a gonadotrophin secretion resembling that of the male. Up to 10 days of age in the rat (and approximately the same time in mice: Barraclough \& Leathem, 1954), the hypothalamus appears to be sensitive to androgens and in the presence of, for example, testosterone, will subsequently assume male characteristics.

Treatment with the tranquillizer, chlorpromazine (Largactil), has been shown to impede the development of the male pattern of gonadotrophin control in rats if given during the first 10 days of life. Ladosky, Kesikowski \& Gaziri (1970) have demonstrated that a single injection of $20 \mu \mathrm{g}$ chlorpromazine (CPZ)/g body weight given to newborn male rats on Days 1, 5, 8, 12 or 15 post partum inhibited testicular development, as assessed by the proportion of seminiferous tubules containing spermatids at 108 days of age. In contrast to this, injection of CPZ on Day 10 advanced the onset of spermatogenesis. The proportion of allografted ovaries showing luteinization 60 days after grafting was used as a measure of $\mathrm{LH}$ secretion: on this basis, $\mathrm{LH}$ secretion appeared to be stimulated by CPZ injection on Days 1, 5, 8 and 10. The peak of spermatogenesis in the animals injected on Day 10 coincided with a high proportion of luteinization in the allografted ovaries; otherwise, the correlation between the estimates of $\mathrm{LH}$ secretion and those of testis maturity was not good.

The present investigation was designed to investigate further the effects of CPZ treatment during the early postnatal period on the subsequent development of testis maturity, using a different species, the mouse.

Forty-four newborn mice of the LACA strain were injected subcutaneously 
with a single dose of CPZ dissolved in distilled water at a concentration of $20 \mu \mathrm{g}$ in $0.01 \mathrm{ml}$. A $0.01 \mathrm{-ml}$ vol. of this solution per $\mathrm{g}$ body weight (and hence a dose of $20 \mu \mathrm{g} / \mathrm{g}$ body weight) was given on Days $4,6,7,8,9$ and 10 after birth (Day 1 = day following birth). The recipients were killed at 30 days of age. The testes and seminal vesicles were removed and weighed. The former were fixed in Bouin's solution, embedded in paraffin wax, sectioned at $8 \mu \mathrm{m}$ and stained with Heidenhain's haematoxylin and eosin. Equivalent untreated mice (seven) served as controls.

After staining, the proportions of tubules containing spermatids, spermatozoa, and spermatozoa free in the lumen of the tubules, were assessed by scoring twenty-five randomly selected tubules from each mouse.

The results are given in Table 1. Injection with CPZ resulted in a general increase in the proportion of tubules which contained spermatids, spermatozoa, and luminal spermatozoa. A significantly $(P<0.001)$ greater effect was noted in

Table 1. Testis maturity, testis weight, and seminal vesicle weight of mice injected after birth with chlorpromazine

\begin{tabular}{|c|c|c|c|c|c|c|}
\hline \multirow{2}{*}{$\begin{array}{l}\text { Day of } \\
\text { injection }\end{array}$} & \multirow{2}{*}{$\begin{array}{l}\text { No. of } \\
\text { mice }\end{array}$} & \multicolumn{3}{|c|}{ No. of tubules which contained: } & \multirow{2}{*}{$\underset{(m g)}{\text { Testis } w t}$} & \multirow{2}{*}{$\begin{array}{c}\text { Seminal vesicle } \\
w t \\
(m g)\end{array}$} \\
\hline & & Spermatids & Spermatozoa & $\begin{array}{c}\text { Luminal } \\
\text { spermatozoa }\end{array}$ & & \\
\hline $\begin{array}{r}4 \\
6 \\
7 \\
8 \\
9 \\
10\end{array}$ & $\begin{array}{r}5 \\
4 \\
4 \\
11 \\
10 \\
10\end{array}$ & $\begin{array}{c}3 \cdot 4 \pm 0 \cdot 7 \\
6 \cdot 0 \pm 2 \cdot 1 \\
16 \cdot 5 \pm 1 \cdot 2 * * * \\
7 \cdot 0 \pm 0 \cdot 8^{* *} \\
11 \cdot 7 \pm 0 \cdot 8^{* * *} \\
46 \pm 1 \cdot 1\end{array}$ & $\begin{array}{c}0.6 \pm 0.2 \\
3.5 \pm 1 \cdot 4 * \\
12.5 \pm 0.3^{* * *} \\
1.7 \pm 0.5 \\
4 \cdot 6 \pm 0.6 * * * \\
1.4 \pm 0.4\end{array}$ & $\begin{array}{l}0.0 \pm 0 \cdot 0 \\
1 \cdot 3 \pm 0.5 * \\
8 \cdot 3 \pm 0.5 * * * \\
0.2 \pm 0 \cdot 1 \\
0.5 \pm 0 \cdot 2 \\
0.2 \pm 0.2\end{array}$ & $\begin{array}{l}65 \cdot 7 \pm 5 \cdot 5 \\
80 \cdot 6 \pm 12 \cdot 2 \\
99.0 \pm 4 \cdot 1 * \\
69.9 \pm 4 \cdot 1 \\
70 \cdot 8 \pm 2 \cdot 6 \\
78 \cdot 3 \pm 4.9\end{array}$ & $\begin{array}{c}6 \cdot 8 \pm 1 \cdot 2 \\
15 \cdot 0 \pm 2 \cdot 2^{*} \\
30 \cdot 0 \pm 4.4 * * * \\
8 \cdot 1 \pm 1 \cdot 0 \\
10 \cdot 2 \pm 0.9 \\
10 \cdot 2 \pm 1.5\end{array}$ \\
\hline Control & 7 & $2 \cdot 9 \pm 0.8$ & $0.3 \pm 0.2$ & $0.0 \pm 0.0$ & $64 \cdot 5 \pm 9 \cdot 1$ & $7 \cdot 8 \pm 1 \cdot 6$ \\
\hline
\end{tabular}

Values expressed as means \pm S.E. (for twenty-five tubules). Mice received a single subcutaneous injection of $20 \mu \mathrm{g}$ chlorpromazine/g body weight.

$$
* P<0.05 ; * * P<0.01 ; * * * P<0.001 \text { ( } t \text { test comparisons with controls). }
$$

animals treated at 7 days of age. This was associated with a greater testis weight (given as the total weight of both testes) and seminal vesicle weight for mice treated on that day. The seminal vesicle (SV) and testis $(\mathrm{T})$ weights were closely related $(\log \mathrm{SV}=0.156+0.011 \mathrm{~T} ; r=0.766, P<0.001)$.

With the exception of rats treated on Day 10, Ladosky et al. (1970) obtained reduced spermatogenesis, and hence retarded sexual maturation, at the age of approximately 110 days after a single injection of CPZ. Using the same dose in relation to body weight $(20 \mu \mathrm{g} / \mathrm{g}$ ), we obtained a general increase (advance) in spermatogenesis at 30 days of age, assessed as the proportion of testis tubules containing spermatids, spermatozoa, or luminal spermatozoa. Sexual maturation had therefore been accelerated.

The consistent relationship between the weight of the androgen-dependent seminal vesicles and testis weight indicates that the endocrine as well as spermatogenic function of the testis was affected by CPZ treatment.

The mechanism of action of CPZ in this case is not clear. In view of the conclusion of Clermont \& Harvey (1967) that 'the rate of development of germ cells is not influenced by hormones', it is likely that it is the time of onset of 
spermatogenesis, rather than its rate, which has been affected. Possibly, CPZ at this dose level acts centrally by reducing the sensitivity of the hypothalamus to a negative feedback stimulus from the testes, resulting in a premature rise in LH release from the pituitary. The reason for the opposite result, and the general inhibition of spermatogenesis, or retardation of its onset, obtained by Ladosky et al. (1970) is not clear.

In other respects, our results parallel those of Ladosky et al. (1970). In both studies, injection of CPZ on one day advanced spermatogenesis to a considerably greater extent than injection on any other day; Day 7 in our experiments, Day 10 in those of Ladosky. Although the reasons for this are unknown, it suggests that events during the 'critical period' for sexual maturation of the hypothalamus are similar in mice and rats, although according to a different time scale.

Treatment with a CNS depressant during the first few days of life, therefore, affects the later development of sexual maturity by advancing the onset of spermatogenesis. This is detectable at 30 days of age, and the effect is particularly marked with injection carried out on the 7 th day of age.

\section{REFERENCES}

Barraclough, C. A. (1966) Modifications in the GNS regulation of reproduction after exposure of prepubertal rats to steroid hormones. Recent Prog. Horm. Res. 22, 503.

Barraclough, C. A. (1968) Alterations in reproductive function following prenatal and early postnatal exposure to hormones. Adv. reprod. Physiol. 3, 81.

Barraclough, G. A. \& Leathem, J. H. (1954) Infertility induced in mice by a single injection of testosterone propionate. Proc. Soc. exp. Biol. Med. 85, 675.

Clermont, Y. \& Harvey, S. C. (1967) Effects of hormones on spermatogenesis in the rat. Ciba Fdn Colloq. Endocr. 16, 173.

Harris, G. W. (1964) Sex hormones, brain development and brain function. Endocrinology, 75, 627.

LAdOSKY, W., KesIKoWsKI, W. M. \& GazIRI, I. F. (1970) Effect of a single injection of chlorpromazine into infant male rats on subsequent gonadotrophin secretion. $\mathcal{F}$. Endocr. 48, 151. 